\title{
Availability of GTP-Sepharose for the Purification of Glutamate Dehydrogenase from Eel Liver
}

\author{
Seiichi HAYASHI* and Zentaro OOSHIRO*
}

(Received July 12, 1976)

\begin{abstract}
Glutamate dehydrogenase from eel liver was purified 75.5 fold in $33 \%$ yield by ammonium sulfate fractionation, protamine and heat treatment, gel filtration and affinity chromatography on GTP-Sepharose. When the partially purified enzyme from gel filtration was applied to a GTP-Sepharose column, it was retained with very few other proteins and recovered in 80 to $90 \%$ yield.

The high affinity for ADP of glutamate dehydrogenase from eel liver was applied to the purification of this enzyme by affinity chromatography. Although this enzyme was retained on the ADP-Sepharose column, it could not be eluted either by a $\mathrm{KCl}$ gradient or by a pulse of $\mathrm{NADH}$.
\end{abstract}

Glutamate dehydrogenase (EC 1.4.1.2) is a key enzyme in ammonia metabolism and has been studied extensively by numerous authors ${ }^{1,2,3)}$. In liver of eel, Anguilla japonica, it is supposed that glutamate dehydrogenase plays an important role in the regulation of nitrogen metabolism. However very little is known about this aspect and the enzyme. ${ }^{4)}$

This paper reports a method for the purification of glutamate dehydrogenase from eel liver by GTP-Sepharose. The use of affinity chromatography for the selective binding of specific proteins has proved extremely useful for the purification of a number of en$z^{2 y m e s}{ }^{5}$. Glutamate dehydrogenase from eel liver, like the enzyme from other sources, has the high affinity for GTP which is a powerful inhibitor. ${ }^{8)}$ We describe that the affinity chromatography on GTP-Sepharose was useful for the purification of this enzyme.

\section{Experimental Procedures}

Materials L-Glutamic acid, $\alpha$-ketoglutaric acid and protamine sulfate were purchased from Wako Chemicals $\mathrm{Co} . \mathrm{NAD}^{+}$and $\mathrm{NADH}$ were obtained from Oriental Yeast $\mathrm{Co}$. Sephadex G-150 and CNBr-activated Sepharose were the product of Pharmacia. GTP, ATP, ADP and AMP were obtained from Yamasa Soybean Souce Co. CTP and ITP were purchased from Sigma Chemical Co. L-glutamate $\gamma$-methylester was purchased from Protein Research Foundation. Other chemicals were obtained from standard commercial sources.

Preparation of acetone powder from eel livers The acetone powder of eel livers was

* Faculty of Fisheries, Kagoshima University, Kagoshima（林 征一・大城善太郎：麻児帛大学水産学 部)。 
prepared essentially as described by L. CoRMAN et al. ${ }^{7}$ When the livers were homogenized in distilled water or appropriate buffers, difficulties attributable to the excessive quantities of oil and fat were encountered. These obstacles were neatly obviated by resort to an acetone powder. A suitable quantity of minced eel livers was homogenized with approximately 10 volumes of acetone $\left(-20^{\circ} \mathrm{C}\right)$ by Polytoron homogenizer. The homogenate was filtered and the precipitate was suspended and rehomogenized in 5 volumes of $n$ butanol $\left(-20^{\circ} \mathrm{C}\right)$. After filtration, the residue was again extracted with a few volumes of acetone and refiltered. The precipitate was then washed with 2 volumes of anhydrous ether $\left(-20^{\circ} \mathrm{C}\right)$. The leached "cake" was raked together and dried at room temperature under reduced pressure.

Extraction The acetone powder was extracted with 10 volumes of $0.1 \mathrm{M}$ Tris- $\mathrm{HCl}$ buffer ( $\mathrm{pH} \mathrm{8.0)}$ at room temperature for $1 \mathrm{hr}$.

Preparation of GTP-Sepharose The GTP-Sepharose was prepared essentially according to R. J. JACKSON et al. ${ }^{8)}$ and C. Godinot et al. ${ }^{9)}$ CNBr-activated Sepharose, $5 \mathrm{~g}$, was suspended in $100 \mathrm{ml}$ of cold $1 \mathrm{mM} \mathrm{HCl}$ for $10 \mathrm{~min}$, filtered with glass filter and washed with $900 \mathrm{~m} l$ of cold $1 \mathrm{mM} \mathrm{HCl}$. The gel was washed with $1.5 l$ of water and bufferized with $1 l$ of $0.1 \mathrm{M} \mathrm{NaHCO}$ buffer (pH 9.0). Suspension of the gel, $50 \mathrm{ml}$, and $1.5 \mathrm{~g}$ of L-glutamate $\gamma$-methylester in $20 \mathrm{ml}$ of $0.1 \mathrm{M} \mathrm{NaHCO}_{3}$ buffer (adjusted to $\mathrm{pH} 9.0$ with $1 \mathrm{~N}$ $\mathrm{NaOH}$ ) was mixed. The mixture was shaken at room temperature for $2 \mathrm{hr}$ and allowed to stand for about 1 to $2 \mathrm{hr}$. The gel was washed with $1.5 \mathrm{l}$ of water. Hydrazine hydrate $(85 \%), 59 \mathrm{ml}$, in flask $(300 \mathrm{ml})$ was preincubated at $70^{\circ} \mathrm{C}$ for about $10 \mathrm{~min}$. Then $\mathrm{L}-$ glutamate $\gamma$-methylester-Sepharose was added dropwise to the hydrazin hydrate and incubated at $70^{\circ} \mathrm{C}$ for $15 \mathrm{~min}$. After incubation the hydrazide gel was cooled to room temperature and washed with $1.5 l$ of water.

On the other hand $90 \mu$ moles of GTP in $10 \mathrm{~m} l$ of 0.1 M citrate phosphate buffer (pH5.0) was oxidized by $1.0 \mathrm{ml}$ of $0.1 \mathrm{M}$ periodate at room temperature for $30 \mathrm{~min}$ in the dark. To destroy excess periodate, $0.4 \mathrm{~m} l$ of ethyleneglycol $(0.22 \%)$ was added and the mixture was oxidized an additional $10 \mathrm{~min}$.

Periodate oxidized GTP and hydrazide-Sepharose were mixed and shaken for $2 \mathrm{hr}$ at room temperature. To block the residual hydrazide, $0.06 \mathrm{~m} l$ of formaldehyde $(37 \%)$ was added to the mixture and the mixture was shaken an additional $1 \mathrm{hr}$.

Then the gel was washed with $1 l$ of cold $0.1 \mathrm{M}$ phosphate buffer-5 mM EDTA ( $\mathrm{pH} 6.8$ ), with $1 l$ of cold $2 \mathrm{M} \mathrm{KCl}$ and with $1.5 l$ of cold water and bufferized with $1.5 l$ of cold $0.05 \mathrm{~m}$ Tris- $\mathrm{HCl}$ buffer- $1 \mathrm{~mm}$ EDTA (pH 7.5).

The coupling yield of L-glutamate $\gamma$-methylester to Sepharose was determined by colorimetric method using ninhydrin reagent. The yield of covalent binding of GTP to the hydrazide-Sepharose was determined by measuring absorbance at $253 \mathrm{~m} \mu$.

Preparation of ADP-Sepharose ADP-Sepharose was prepared according to the pro- 
cedures described in "Preparation of GTP-Sepharose" except that ADP were used as a ligand instead of GTP. The yield of covalent binding of ADP was determined by measuring absorbance at $260 \mathrm{~m} \mu$.

Enzyme assays and protein determination In case of reductive amination the assay mixture $(4.0 \mathrm{ml})$ consisted of $50 \mathrm{mM} \mathrm{NH}_{4} \mathrm{Cl}, 20 \mathrm{mM} \alpha$-ketoglutarate (adjusted to $\mathrm{pH} 8.0$ with $1 \mathrm{M} \mathrm{KOH}), 0.15 \mathrm{~mm} \mathrm{NADH}$ and $20 \mathrm{~mm}$ Tris- $\mathrm{HCl}$ buffer ( $\mathrm{pH} 8.0)$ containing $0.1 \mathrm{~mm}$ EDTA. The reaction was initiated by the addition of $50 \mu l$ of enzyme solution. The oxidation of $\mathrm{NADH}$ at $30^{\circ} \mathrm{C}$ was followed by the decrease in absorbance at $340 \mathrm{~m} \mu$ with a Hitachi EPU-2A. One enzyme unit was defined as the amount of enzyme that catalyzed the conversion of $1 \mu$ mole of NADH per min under the assay conditions.

In case of oxidative deamination the assay mixture $(4.0 \mathrm{ml})$ consisted of $0.1 \mathrm{M}$ Tris$\mathrm{HCl}$ buffer $\left(\mathrm{pH} \mathrm{8.0)}, 0.1 \mathrm{~m}\right.$ glutamate and $5 \mathrm{mM} \mathrm{NAD}^{+}$. Activity was measured by following the increase in absorbance at $340 \mathrm{~m} \mu$.

Protein was determined by the procedure of LowRY et al. ${ }^{10)}$ or from absorbance at $280 \mathrm{~m} \mu$.

\section{Results}

A representative procedure is described below for the supernatant solution extracted from the acetone powder obtained from $400 \mathrm{~g}$ (wet weight) of eel livers.

Ammonium sulfate fraction The supernatant solution was brought to $25 \%$ saturation by slow addition of solid $\left(\mathrm{NH}_{4}\right)_{2} \mathrm{SO}_{4}$ with continuous stirring. After $20 \mathrm{hr}$ the suspension was centrifuged at $15,000 \times g$ for $30 \mathrm{~min}$ and the supernatant was taken to $60 \%$ saturation in $\left(\mathrm{NH}_{4}\right)_{2} \mathrm{SO}_{4}$. After $20 \mathrm{hr}$ the suspension was centrifuged as above. The pellet contained most of the enzyme. The pellet was dissolved in a few volumes of $0.1 \mathrm{M}$ Tris- $\mathrm{HCl}$ buffer (pH 8.0) containing $1 \mathrm{mM}$ EDTA and dialyzed against $0.01 \mathrm{~m}$ Tris- $\mathrm{HCl}$ buffer- $0.1 \mathrm{~mm}$ EDTA (pH 8.0).

Protamine precipitation of nucleoprotein and heat treatment Protamine sulfate was dissolved in the dialyzed solution at a concentration of $10.75 \mathrm{mg}$ per $100 \mathrm{mg}$ of protein. After $20 \mathrm{~min}$, the precipitate was removed by centrifugation for $30 \mathrm{~min}$ at $15,000 \times g$. The supernatant solution was heated at $55^{\circ} \mathrm{C}$ for $8 \mathrm{~min}$ with constant stirring. The precipitate was removed by centrifugation. Then the supernatant was concentrated on a XM 50 Amicon ultrafiltration membrane.

Gel filtration The concentrated solution was applied to a column $(2.6 \times 90 \mathrm{~cm})$ of Sephadex G-150 previously equilibrated with $0.01 \mathrm{M}$ Tris- $\mathrm{HCl}$ buffer- $0.1 \mathrm{M}$ EDTA ( $\mathrm{pH}$ 8.0) containing $0.1 \mathrm{M} \mathrm{NaCl}$. The enzyme was eluted with the same buffer at a flow rate of $15 \mathrm{~m} l$ per hr and fractions of $5 \mathrm{~m} l$ were collected as shown in Fig. 1. Fractions with high specific activity were pooled, concentrated on a XM 50 Amicon ultrafiltration membrane and dialyzed against $0.05 \mathrm{M}$ Tris- $\mathrm{HCl}$ buffer- $1 \mathrm{~mm}$ EDTA (pH 7.5). 


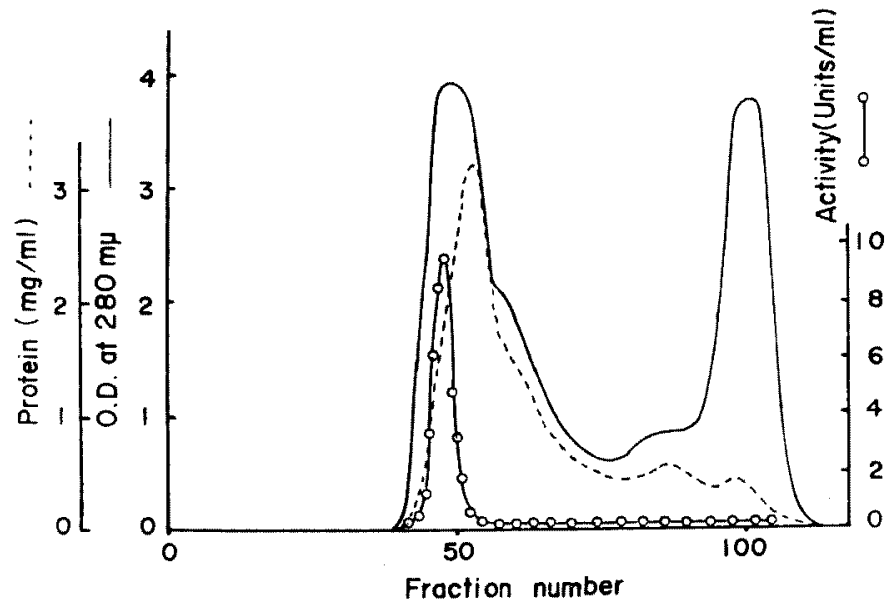

Fig. 1. Gel filtration of glutamate dehydrogenase in $0.01 \mathrm{M}$ Tris- $\mathrm{HCl}$ buffer- $0.1 \mathrm{~mm}$ EDTA-0.1 $\mathrm{M}$ $\mathrm{NaCl}$ at $\mathrm{pH} 8.0$ on a column $(2.4 \times 90 \mathrm{~cm})$ of Sephadex $\mathrm{G}-150$.

Affinity chromatography on GTP-Sepharose column The results of experiments for the preparation of GTP-Sepharose indicated that about $130 \mu$ moles of L-glutamate $\gamma$ methylester as a spacer were coupled per $\mathrm{m} l$ of settled gel and approximately $2 \mu$ moles of oxidized GTP were bound per $\mathrm{m} l$ of settled gel. However the release of phosphates of GTP was not taken into consideration for the determination of the coupling yield of

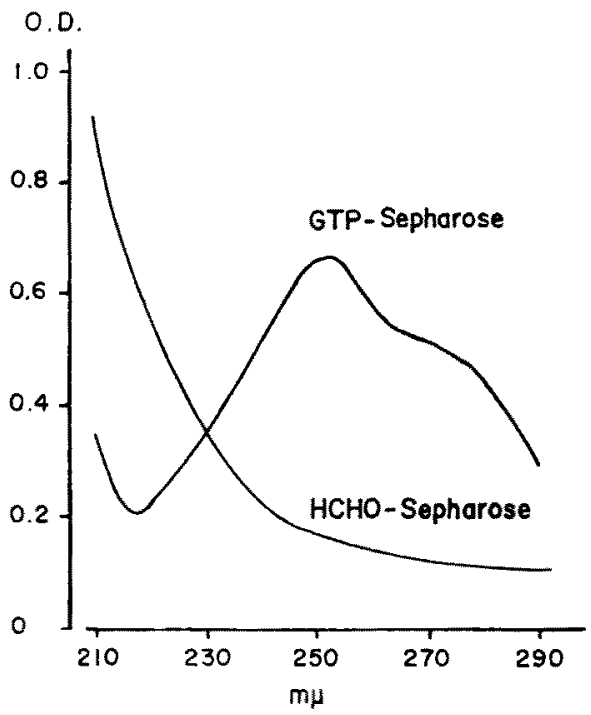

Fig. 2. UV-spectrum of GTP-Sepharose. GTP-Sepharose was suspended in $0.05 \mathrm{M}$ Tris-HCl buffer ( $\mathrm{pH} 7.5$ ) containing $1 \mathrm{~mm}$ EDTA.
GTP. The UV-spectrum of GTP-Sepharose was shown in Fig. 2.

Glutamate dehydrogenase fraction separated by gel filtration was applied to a column $(1.6 \times 14.5 \mathrm{~cm})$ of GTP-Sepharose previously equilibrated with $0.05 \mathrm{M}$ Tris$\mathrm{HCl}$ buffer ( $\mathrm{pH} 7.5$ ) containing $1 \mathrm{~mm}$ EDTA. After washing the column with $75 \mathrm{ml}$ of the equilibrated buffer, the enzyme was eluted with a linear gradient of $\mathrm{KCl}$, formed by placing $100 \mathrm{~m} l$ of the equilibrated buffer in the mixing chamber and $100 \mathrm{ml}$ of the same buffer containing $1 \mathrm{M} \mathrm{KCl}$ in the reservoir. Fractions of $5 \mathrm{~m} l$ were collected at a flow rate of $20 \mathrm{~m} l$ per hr. The enzyme was eluted at approximately $0.1 \mathrm{M} \mathrm{KCl}$. A typical elution profile is shown in Fig. 3. 


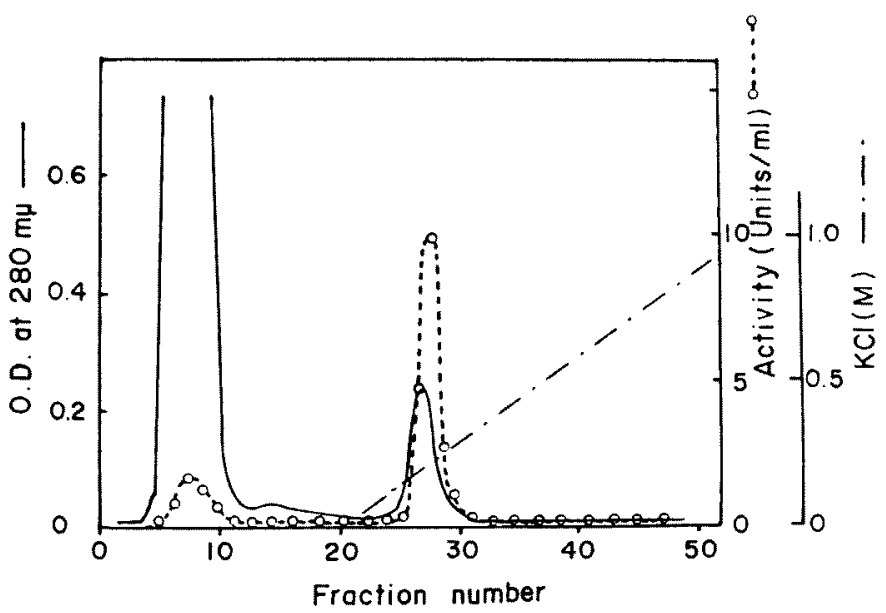

Fig. 3. Chromatography of glutamate dehydrogenase on GTP-Sepharose. Enzyme protein $(18.56 \mathrm{mg}$ ) in $0.05 \mathrm{M}$ Tris- $\mathrm{HCl}$ buffer-1 mM EDTA (pH 7.5) was applied to a $1.6 \times 14.5 \mathrm{~cm}$ column, equilibrated with the same buffer.

Table 1. Summary of the results of the purification

\begin{tabular}{lcccc}
\hline \multicolumn{1}{c}{ Procedure } & $\begin{array}{c}\text { Protein } \\
\mathrm{mg}\end{array}$ & $\begin{array}{c}\text { Total } \\
\text { Units }\end{array}$ & $\begin{array}{c}\text { S. A. } \\
\text { (units/mg protein) }\end{array}$ & $\begin{array}{c}\text { Recovery } \\
\%\end{array}$ \\
\hline $25-60 \%\left(\mathrm{NH}_{4}\right)_{2} \mathrm{SO}_{4}$ & 4814 & 2147 & 0.45 & 100 \\
Protamine and $\mathrm{Heat}_{\mathrm{m}}$ & 1681 & 1731 & 1.03 & 81 \\
Sephadex $\mathrm{G}-150$ & 184 & 787 & 4.28 & 37 \\
GTP-Sepharose & 21 & 708 & 33.79 & 33 \\
\hline
\end{tabular}

The purification procedure is summarized in Table 1 .

Affinity chromatography on ADP-Sepharose column ADP-Sepharose prepared indicated that approximately $2 \mu$ moles of oxidized ADP were bound per $\mathrm{m} l$ of settled gel. The enzyme partially purified by gel filtration was applied to a column $(1.6 \times 14 \mathrm{~cm})$ of ADP-Sepharose previously equilibrated with $0.05 \mathrm{M}$ Tris- $\mathrm{HCl}$ buffer ( $\mathrm{pH} 7.5$ ) containing 1 mm EDTA. Though the enzyme was retained on the ADP-Sepharose column, it could not be eluted either by a $\mathrm{KCl}$ gradient or by addition of $1 \mathrm{~m} l$ of $1 \mathrm{~mm} \mathrm{NADH}$.

\section{Discussion}

Glutamate dehydrogenase from eel liver was purified 75.5 fold with a yield of $33 \%$ by our procedure including affinity chromatography on the GTP-Sepharose. When the enzyme partially purified by the gel filtration was applied to the column of the GTPSepharose, it was retained with very few other proteins and the recovery of enzyme activity from the column ranged from 80 to $90 \%$. The specific activity of the enzyme eluted from the column was 33.8 units per $\mathrm{mg}$ protein. However polyacrylamide gel electrophoresis of the concentrated eluate revealed the enzyme was not homogeneous. 
About 3 units of the glutamate dehydrogenase were bound per $\mathrm{m} l$ of GTP-Sepharose gel. This retention capacity was about the half of that reported by C. Godinor et al. ${ }^{9}$

Since L-glutamate $\gamma$-methylester could not become the substrate for the oxidative deamination instead of L-glutamate and did not inhibit the reductive amination, it was assumed that there was no possibility of L-glutamate $\gamma$-methylester residue of the gel to be a ligand.

It was found from the effects of nucleotides on the glutamate dehydrogenase partially purified from eel liver that ADP strikingly accelerated $\mathrm{NAD}^{+}$reduction and $\mathrm{NADH}$ oxidation. Then the purification of the enzyme by the affinity chromatography on ADP-Sepharose was examined. Although the enzyme was retained on the ADP-Sepharese column, it could not be eluted either by a $\mathrm{KCl}$ gradient or by a pulse of NADH. It is assumed that the affinity for ADP of the enzyme is stronger than for GTP or that the mechanism of the interaction between the enzyme and immobilized GTP is different from it between the enzyme and immobilized ADP.

Affinity chromatography on immobilized adenosine-5'-monophosphate has been utilized to separate and purify dehydrogenases and kinases ${ }^{11,12)}$. It is thought that $5^{\prime}$-AMP is a suitable ligand for affinity chromatography since it is an inhibitor for a great number of both $\mathrm{NAD}^{+}$-dependent and other enzymes. However the glutamate dehydrogenase from eel liver is not inhibited by $5^{\prime}$-AMP. Therefore it is assumed that AMPSepharose is not useful for the purification of the enzyme.

BLumentHal et al. ${ }^{13)}$ reported purification of Neurospora glutamate dehydrogenase by affinity chromatography on a resin containing $\mathrm{N}$-carboxymethyl-L-glutamate but elution of the enzyme could be obtained only with an acidic buffer that induced partial inactivation.

From the present investigation it may be concluded that the affinity chromatography on GTP-Sepharose was very usuful for the purification of the glutamate dehydrogenase from eel liver.

\section{References}

1) H. F. Fisher: in "Advances in Enzymology" (ed. by A. Meister), Vol. 39, John Wiley and Sons, New York, London, Sydney and Toronto, 1973, pp. 369-417.

2) H. EISENBERG: in "Carrent Topics in Biochemistry" (ed. by C. B. ANFInSEN and A. N. SCHECHTER), Academic Press, New York and London, 1973, pp. 43-72.

3) M. Sato, Y. Sato, and Y. Tsuchiya: This Bull, 41, 337-341 (1975).

4) R. L. Mcbean, M. J. Neppel, and L. Goldstein: Comp. Biochem. Physiol., 18, 909-920 (1966).

5) M. WilcheK and R. LAMED: in "Methods in Enzymology" (ed. by W. B. JACOBY and M. WILCHEK), Vol. 34, Academic Press, New York, San Francisco and London, 1974, pp. 475-479.

6) C. Frieden: J. Biol. Chem., 240, 2028-2035 (1965).

7) L. Corman and A. Inamdar: in "Methods in Enzymology" (ed. by H. TABor and C. W. TABor), Vol. 17A, Academic Press, New York, San Francisco and London, 1970, pp. 844-850.

8) R. J. Jackson, R. M. Wolcort, and T. ShIota: Biochem. Biophys. Res. Commun., 51, 428-435 
(1973).

9) C. Godinot, J. H. Julliard, and D. C. Gantheron: Anal. Biochem., 61, 264-270 (1974).

10) O. H. Lowry, N. J. Rosebrough, A. L. Farr, and R. J. Radall: J. Biol. Chem., 193, 265-275 (1951).

11) D. B. Craven, M. J. Harrey, C. R. Lowe, and P. D. G. Dean: Eur, J. Biochem., 41, 329-333 (1974).

12) H. Gilford, P. O. Larsson, and K. Mosbach: Chemica Scripta, 2, 165-170 (1972).

13) K. M. Blumenthal and E. L. Smith: J. Biol. Chem., 248, 6002-6008 (1973). 